Extended Abstract

\title{
The Biological Tricks That Knit A Global Brain
}

\author{
Howard Bloom ${ }^{1, *}$ \\ ${ }^{1}$ Author of: The Lucifer Principle: A Scientific Expedition Into the Forces of History, Global Brain: \\ The Evolution of Mass Mind From The Big Bang to the 21st Century, The Genius of the Beast: A \\ Radical Re-Vision of Capitalism, and The God Problem: How A Godless Cosmos Creates. Former \\ Core Faculty Member, The Graduate Institute, Meriden, CT; former visiting scholar, Graduate \\ Psychology Department, New York University.
}

E-Mails: howlbloom@aol.com

* Author to whom correspondence should be addressed; Tel.: +1 718-622-2278; Fax: +1-718-6222278, 705 President Street, Brooklyn, New York, USA 11215.

Accepted: 20 March, 2015

\section{Introduction}

When it comes to your deepest, darkest nature, there's a whole lot of accusing going on. The fight or flight folks tell you that your biology comes complete with an overwhelming instinct for survival. Rational-choice-obsessed specialists like economists and evolutionary psychologists claim that you are not only preprogrammed for survival at all costs, but that you are wired to maximize your personal gains. And evolutionary biologists like William Hamilton, Richard Dawkins and Robert Trivers assert that you are biologically programmed to maximize the spread of your selfish genes.

These claims about your most intimate nature are concealed in the very foundations of many of the social and evolutionary sciences, from evolutionary biology and evolutionary psychology to political science, sociology, philosophy, and economics. They are buried deep below the surface in the form of assumptions - often hidden assumptions. But these assumptions about your innermost self are only half-right. More important, they are half-wrong. And the half that's wrong throws evolutionary and social sciences way off base. Which may explain why one of the most lauded and mathematically savvy economists of his day, Irving Fisher, told the New York Times in mid-October, 1929, that stocks 
were about to go "a good deal higher within a few months." Then on October $29^{\text {th }}$ came Black Tuesday and the great crash of 1929.

Like the economy, your biology often refuses to follow the paths that scientific assumptions about survival and selfishness would predict. Yes, some of your internal mechanisms do work to stack up your survival advantages. And to maximize your sexual prizes. But you are also plagued with internal mechanisms that do the very opposite, biological mechanisms that hobble you: depression, anxiety, brain freeze, and even impulses toward suicide. What's more, on occasion you are willing to sacrifice your life for something higher than yourself. Ten million followed that inner call in the First World War.

Your self-destruct mechanisms - human self-destruct mechanisms--are not unique. They've been integral to the 3.85-billion-year history of life. They are similar to apoptotic mechanisms, the "programmed cell death" mechanisms, that individual cells in a bacterial society or in your body use to commit suicide.

Why do self-destruct mechanisms of this sort exist? Because the believers in the survival instinct, the rational choice model, and the selfish gene miss something. Something big. Your biology is not wired strictly for personal gain. It is wired to make you a component in something far greater than yourself. It is wired to make you a module in a collective learning machine, a complex adaptive system, a parallel-processing search engine, a group IQ, a social intelligence. You are wired to be a neuron in a social brain.

A neuron in a brain that, like you, collaborates to make something bigger than itself: a global brain.

\section{Methods}

This talk is based on the research for my first two books, The Lucifer Principle: A Scientific Expedition into the Forces of History and Global Brain: The Evolution of Mass Mind from the Big Bang to the $21^{\text {st }}$ Century. That research drew heavily on work in evolutionary biology, evolutionary psychology, artificial intelligence, animal behavior, experimental psychology, neuroscience, psychoneuroimmunology, anthropology, and history. It involved the use of over 4,000 reference sources.

\section{Results and Discussion}

The common wisdom - and the accepted view in evolutionary biology — is that we humans and our animal cousins are built with a survival instinct. An instinct that watches out for our personal survival, and for personal survival ahead of everything else.

Yet when we encounter a saber tooth tiger on a pathway, we have three modes of response: not just Walter Bradford Cannon's fight or flight, but fight, flight, or freeze. And freeze can be suicide. That's 
not the only suicidal mechanism locked into our biology. When you're about to take that allimportant math test and you've studied for weeks, then finally open the test booklet, your mind locks up. It refuses to remember a thing. That anxiety blackout is not a product of a patriarchal civilization, industrialism, or capitalism. It is a product of your biology.

When you are fired or your wife tells you she is leaving you, your survival instinct should put your mind into overdrive. It should give you the juice to hunt with energy and creativity for your next step. But high-power cognitive processing is not what your biology serves up. Instead, it bogs you in depression, a state in which it's hard to think of even tying your shoes.

How do mental paralysis and depression up your odds of survival? They don't.

So what gives? How could natural selection possibly favor such obvious self-destruct mechanisms? The answer is in the algorithms that power collective intelligences, mass learning machines like neural nets and the immune system. Rules that turn down the flow of resources and influence to the nodes that fail to cope with the problems of the moment and turn up the resource-flow and the influence of the nodes that have a handle on things.

\section{Conclusions}

We need a radical overhaul of the assumptions underlying many of our sciences and many of our pop-cultural beliefs. Yes, we need to recognize our survival instincts and our selfish biological builtins. But we also need to see our role in something higher than ourselves-complex adaptive systems, neural-net-like collective learning machines. If we do, many of the "irrational" mysteries that make the predictions of so many social scientists wrong may suddenly appear to be rational after all.

\section{References and Notes}

1. Bloom, H. The Lucifer Principle: A Scientific Expedition into the Forces of History; Atlantic Monthly Press: New York, USA, 1995.

2. Bloom, H. Global Brain: The Evolution of Mass Mind from the Big Bang to the 21st Century; John Wiley \& Sons: New York, USA, 2000.

3. Bredesen, D. Neural Apoptosis. Annals of Neurology 1995, Vol 38, 839-851.

4. Cannon, W.B. Bodily Changes in Pain, Hunger, Fear and Rage: An Account of Recent Researches into the Function of Emotional Excitement; D. Appleton: New York, USA, 1915; pp. 202, 275-277.

5. Dawkins, R. The Selfish Gene; Oxford University Press, New York, USA, 1976.

6. Durkheim, E.; Suicide: A Study In Sociology; translated by John A. Spaulding and George Simpson. The Free Press: New York, USA, 1951 (originally published 1897).

7. Haanen, C., Vermes, I. Apoptosis: programmed cell death in fetal development. European Journal of Obstetrics, Gynecology, and Reproductive Biology 1996, Volume 64, Issue 1, 129133. 
8. Harlow, H.F.; Suomi, S.J. "Production and Alleviation of Depressive Behaviors in Monkeys." In Psychopathology: Experimental Models; Maser, J.D.; Seligman, M. Eds.; W.H. Freeman and Company: San Francisco, USA, 1977; pp. 167-170.

9. Holland, J.H. Hidden Order: How Adaptation Builds Complexity; New York, USA: AddisonWesley, 1995.

10. Hopfield, J.J. "Neural networks and physical systems with emergent collective computational abilities." Proceedings of the National Academy of Sciences of the United States of America 1982, Vol. 79, Number 8, 2554-8.

11. Kirschner, M.; Gerhart, J. Evolvability. Proceedings of the National Academy of Sciences of the United States 1998, vol. 95 no. 15, 8420-8427.

12. McClelland, J.L., Rumelhart, D.E. and the PDP Research Group; Parallel Distributed Processing: Explorations in the Microstructure of Cognition, Volume 2: Psychological and Biological Models; A Bradford Book, The MIT Press: Cambridge, MA, USA, 1986.

13. Miller, W.R.; Rosellini, R.A.; Seligman, M. "Learned Helplessness and Depression." In Psychopathology: Experimental Models, Maser, J.D., Seligman, M., Eds.; W.H. Freeman and Company, San Francisco, USA, 1977; pp. 104-130.

14. Nasar, S. Grand Pursuit: The Story of Economic Genius; Simon \& Schuster: New York, USA, 2011; pp. 312-313.

15. Kevin A. Roth, K.A, D'Sa, C. Apoptosis and brain development, Mental Retardation and Developmental Disabilities Research Reviews 2001. Volume 7, Issue 4, 261-266.

16. Tomei, D., Cope, F.O., editors, Apoptosis: the molecular basis of cell death. Cold Spring Harbor Laboratory Press: Plainview, NY, USA, 1991.

17. Wilson, E.O. Sociobiology: The New Synthesis. Harvard University Press: Cambridge, MA, USA, 1975.

18. Wilson, E.O. The Social Conquest of Earth, W.W. Norton: New York, USA, 2012.

19. Wilson, D.S. Does Altruism Exist?: Culture, Genes, and the Welfare of Others (Foundational Questions in Science). Yale University Press: New Haven, Connecticut, USA; 2015.

(C) 2015 by the authors; licensee MDPI and ISIS. This abstract is distributed under the terms and conditions of the Creative Commons Attribution license. 